\title{
Recurrent Childhood Malignant Germ Cell Tumor
}

National Cancer Institute

\section{Source}

National Cancer Institute. Recurrent Childhood Malignant Germ Cell Tumor. NCI

Thesaurus. Code C9221.

The reemergence of a malignant germ cell tumor in children after a period of remission. 